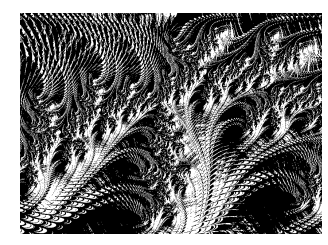

https://doi.org/10.5559/di.30.3.02

\title{
THE EFFECT OF EMOTIONAL INTELLIGENCE ON MATERIALISM AND COMPULSIVE BUYING
}

Beata ŠEINAUSKIENĖ, Aušra RŪTELIONE், Asta TARUTE் School of Economics and Business, Kaunas University of Technology, Kaunas, Lithuania Shahrokh NIKOU

Faculty of Social Sciences, Business and Economics, Åbo Akademi University, Turku, Finland

Rosita LEKAVIČIENÉ

Faculty of Social Sciences, Arts and Humanities, Kaunas University of Technology, Kaunas, Lithuania

UDK: 159.942:616.89-008.444.61

[159.95:159.942]:339.162.34

Original scientific paper

Received: July 29, 2019

Drawing on the escape theory, we propose that emotional intelligence is negatively linked to materialism and compulsive buying. Our research demonstrates that the ability to manage one's emotions is associated with lower levels of materialism and compulsive buying. We also show that materialism functions as the mechanism underlying the emotional intelligence - compulsive buying relationship. Similarly, the ability to understand one's emotions was found to be negatively related to compulsive buying. Contrary to expectations, the path between the understanding of one's emotions and materialism was found to be non-significant, suggesting that the link between emotional intelligence and materialism might not always be direct. As expected, materialism was positively linked to compulsive buying. Our research contributes to the relevant literature with a new antecedent of materialism, namely emotional intelligence.

Keywords: emotional intelligence, compulsive buying, materialism, escape theory

Aušra Rūtelionè, School of Economics and Business, Kaunas University of Technology, Gedimino str. 50, 44239 Kaunas, Lithuania. E-mail: ausra.rutelione@ktu.It 
Research shows that in today's societies consumers are increasingly preoccupied with overconsumption, consequently at risk of being turned into the more severe forms of compulsive buying (hereinafter CB). Approximately 5\% prevalence of $\mathrm{CB}$ across the world indicates that one in every twenty consumers is exposed to addictive buying behaviour (Maraz et al., 2016). Despite the diversity of conceptualisations, empirical results consistently show that $\mathrm{CB}$ is associated with various unwanted psychological, social and financial outcomes. Addictive buying was found to be related to profound life dissatisfaction (Otero-López et al., 2011). Greater CB significantly relates to lower quality of life and results in a substantial monetary cost for compulsive buyers (Zhang et al., 2017). Empirical evidence also provides support for an association between CB and substance abuse/dependence, as well as anxiety disorder (Zhang et al., 2016).

The other dimension widely acknowledged as the dark side of consumer behaviour is materialism (Moschis, 2017), which has been documented as a strong predictor of CB (Dittmar et al., 2014). Extensive research shows that both materialism and CB are linked to poorer subjective well-being (Burroughs \& Rindfleisch, 2002; Kasser \& Ahuvia, 2002). On the other hand, a greater sense of subjective well-being has been attributed to increased emotional intelligence (hereinafter EI) (Sánchez-Álvarez et al., 2016; Zeidner et al., 2012). Thus, if the ability to deal with emotions and subjective well-being is positively connected, then it is plausible that EI has the potential to protect against a disposition towards acquiring possessions and excessive buying.

However, though substantial research on the causes of $C B$ and materialism was conducted, research on the consumer's ability to deal with emotions in explaining the preoccupation with possessions has been scant. The ability to understand and manage emotions is considered to be one of the components of EI. Recent literature suggests that EI may enhance the understanding of behavioural addictions (Kun \& Demetrovics, 2010) as well as materialism (Shrum et al., 2014). Despite the acknowledgement of the relevance of emotions in the domain of consumer behaviour (Kidwell et al., 2008), research that links EI to CB and materialism is sparse. In addition, a systematic literature review of Kun and Demetrovics revealed that the ability to understand and manage emotions should account for the appearance of behavioural addictions, yet the link between behavioural addictions and EI has been relatively under-studied. 
DRUŠ. ISTRAŽ. ZAGREB GOD. 30 (2021), BR. 3, STR. 487-508

ŠEINAUSKIENĖ, B. ET AL.: THE EFFECT OF...
The present study addresses this research gap by exploring the effect of EI on the tendency towards CB through materialism. First, this study contributes to the literature by clarifying the effect of the two dimensions of EI, i.e., the understanding and the management of one's emotions with regard to materialism and CB proclivities. Second, the study elaborates on prior works by examining the mediational process through which EI relates to CB.

\section{LITERATURE REVIEW AND HYPOTHESIS DEVELOPMENT}

\section{The relationship between \\ emotional intelligence and compulsive buying}

Compulsive buying. In consumer behaviour literature, compulsive consumption has been defined by O'Guinn and Faber (1989, p. 148) "as a response to an uncontrollable drive or desire to obtain, use, or experience a feeling, substance, or activity that leads an individual to repetitively engage in a behaviour that will ultimately cause harm to the individual and/or to others". The definition reveals that compulsive consumption is not entirely limited to the consumption of goods. Edwards (1993, p. 72) explains the $C B$ phenomenon through the consumer-spending lens by assigning the ranges of "non-compulsive, recreational, borderline compulsive, compulsive and addicted buying" to the buying continuum. It is commonly accepted to conceptualise $\mathrm{CB}$ as an insurmountable, uncontrolled and repetitive buying pattern, featuring the waste of time and financial resources and stemming from the motivation to alleviate negative mood (Dittmar et al., 2007; Müller \& Roberts, 2005; Otero-López \& Pol, 2013; Ridgway et al., 2008). Our emphasis in this research is on the concept of CB as a continuum.

Emotional intelligence. When explaining EI, there are two primary directions adopted. Researchers (Mayer \& Salovey, 1997; Mayer et al., 2004) representing the first direction view EI as a combination of intelligence and emotion. Therefore, EI measurement tests are in essence very close to IQ tests that require special conditions to be performed.

The second direction, called the 'mixed model approach', construe EI through aspects of character and motivation as well as emotional abilities (Bar-On, 2006; Petrides \& Furnham, 2001). In this study, we use a 'mixed model approach' and define EI as the ability to understand and manage one's emotions measured by self-report methodology.

EI and CB. According to Saraneva and Sääksjärvi (2008), purchasing for compulsive buyers is a part of life and deeply related to the emotions they experience. The emotions of these 
DRUŠ. ISTRAŽ. ZAGREB GOD. 30 (2021), BR. 3, STR. $487-508$

ŠEINAUSKIENĖ, B. ET AL.: THE EFFECT OF... buyers are more intense and affect their self-esteem adversely. While shopping, compulsive buyers try to manage their personal problems and reduce mood swings.

While only a few studies have looked at the association between EI and behavioural addictions, findings point to the existence of a negative relationship. For example, Chien-Huang and Chuang (2005) found that adolescents with low EI were more susceptible to yield to impulsive buying behaviour than were those with high EI. Regarding internet use, Engelberg and Sjöberg (2004) found that frequent internet users score lower than others on EI measurements. A study by Parker et al. (2008) revealed that EI was a moderate to powerful predictor of such addiction-prone behaviours as gambling, using the internet and engaging in video games. Similarly, a study by Beranuy et al. (2009) demonstrated that poor perceived EI was linked to college student misuse of the internet and mobile phones.

Rose and Segrist (2012) note that dysfunction of emotional self-regulation is a primary source of CB. Their study demonstrated that consumers who face difficulties in identifying feelings and exhibit low distress tolerance are more prone to excessive buying. Difficulty in identifying emotions impairs their effective regulation, while greater resilience to stressful situations (attributable to higher EI) enables a reduction in the level of negative emotions (Zeidner et al., 2012). Compared to ordinary buyers, compulsive buyers feel more intense negative emotions before buying (Dittmar, 2004). The pursuit of relief from negative feelings, as O'Guinn and Faber (1989) have pointed out, constitutes the main reason for indulging in $\mathrm{CB}$ behaviour.

Negative emotions prompt consumers with high expectations to escape painful self-awareness via compensatory CB (Kellett \& Bolton, 2009). Therefore, the imaginary possibility of avoiding unacceptable self-awareness and painful feelings is considered the driver of CB (Dittmar, 2004). Furthermore, heightened impulsivity is suggested as related to a propensity for experiential avoidance (Chapman et al., 2006), which stems from the inability to manage emotions. According to escape theory (see Heatherton and Baumeister, 1991) CB is regarded as an effort to avoid adverse inner emotions and shift the focus to external stimuli such as possessions (Müller et al., 2012). In summary, based on the literature review, we suggest:

H1a: Understanding one's emotions and

$\mathrm{H} 1 \mathrm{~b}$ : Managing one's emotions are both negatively related to compulsive buying. 


\section{The relationship between emotional intelligence and materialism}

Materialism. The conceptualisation of materialism centred on personal value orientation reveals the significance of ownership or possession perceived by consumers as a needed or preferred behaviour in pursuing personal goals (Richins \& Dawson, 1992). Values are what determine consumer's choices and behaviour in a wide range of contexts, including consumption. This approach encompasses three interrelated domains: centrality, happiness and success (Richins \& Dawson, 1992; Richins, 2004). The centrality facet conveys the extent to which consumers believe that acquisition and possession of things is essential to their lives. The success facet of materialism is the belief that one's and other people's success might only be signalised and validated by evident material wealth and acquisitions. The happiness facet is associated with the belief that possessions and their acquisition is the main route to happiness and satisfaction with life. The perspective of value orientation, which encompasses the facets of centrality, happiness and success, is predominant in studies of consumer behaviour.

EI and materialism. Studies confirm that ability-based EI facilitates stress resilience and stimulates adaptive behaviour during stressful situations (Schneider et al., 2013). Moreover, trait-related EI was evidenced to be linked to a lower tendency to experience negative emotions and a greater inclination to experience positive emotions (Mikolajczak et al., 2008). Research has also found that individuals, high in trait-related EI, are more prone to employ adaptive (e.g. problem-solving oriented) rather than non-adaptive (e.g. avoidance-based) coping strategies when confronted with negative situations (Mikolajczak et al., 2009; Petrides et al., 2007). Similarly, low ability-based EI has been found to be linked to coping strategies characterised by avoidance (Matthews et al., 2006). Thus, research shows that EI helps protect against choosing harmful emotion regulation strategies (Mikolajczak et al., 2009).

The avoidance coping style is attributable to experiential avoidance (Chapman et al., 2006), which is defined as a person's refusal to be exposed to unwanted internal emotional and behavioural experiences. The reluctance to face unbearable difficulties results in various forms of avoidance or escape behaviour, which might be harmful (Hayes et al., 1996). The propensity to avoid unpleasant thoughts and feelings stems from various psychological and social dysfunctions (Kashdan \& Breen, 2007). Chapman et al. suggest that experiential avoidance possibly stems from a lack of emotional regulation skills. Therefore, the aforementioned notion implicitly presupposes the experiential avoidance and EI links. 
DRUŠ. ISTRAŽ. ZAGREB GOD. 30 (2021), BR. 3, STR. $487-508$

ŠEINAUSKIENE், B. ET AL.: THE EFFECT OF...
Studies provide empirical evidence of the link between experiential avoidance and materialism. For example, Kashdan and Breen (2007) found that strong materialistic values were positively associated with experiential avoidance, where experiential avoidance mediated an association between materialistic values and diminished emotional well-being. Based on the 'escape from self' theory (Heatherton \& Baumeister, 1991), Kashdan and Breen argue that the relationship between materialism and experiential avoidance may be explained by a person's expectation of short-term benefits, which these avoidances' coping strategies may provide - namely feelings of pleasure and relief from psychological pain. The 'escape from self' theory posits that "the motivation to escape from self-awareness begins with a comparison of self against high standards or ideals" (Heatherton \& Baumeister, 1991, p. 89), since the awareness of one's own shortcomings is emotionally painful. Further, Kashdan and Breen suggest that avoidance-based social motives and self-protective and preventive mindsets are more prevalent among materialistic individuals. Emotional experiences characterised by unpleasant states of self-awareness elicit experiential avoidance (Chapman et al., 2006). Materialistic individuals try to fill the gap in their sense of self with possessions, thus, low self-awareness, as a sign of insecurity, is supposed to produce a materialistic response (Burroughs et al., 2013).

The assumption of a negative EI-materialism relationship is further reinforced by findings of Engelberg and Sjöberg (2006), revealing that heightened concern for money is less evident among people with higher EI. However, it should be noted that materialism is a broader concept that extends beyond one's attitude towards money (Dittmar et al., 2014). The materialistic inclination to overspend signifies money being more a means to acquire possessions rather than the praise of money per se (Donnelly et al., 2016). Based on the above discussions, the following hypotheses are suggested:

H2a: Understanding one's emotions is negatively related to materialism.

$\mathrm{H} 2 \mathrm{~b}$ : Managing one's emotions is negatively related to materialism

\section{The relationship between materialism and compulsive buying}

According to Roberts et al. (2008), the CB phenomena is considered to be a less rational consumer behaviour. Moreover, Baker et al. (2013) highlight an existing relationship between $\mathrm{CB}$ and other forms of addictive behaviour and consequences thereof (such as binge eating, depression and unmanageable debt) that negatively affect a consumer's personal life. Since 
DRUŠ. ISTRAŽ. ZAGREB GOD. 30 (2021), BR. 3, STR. $487-508$

ŠEINAUSKIENĖ, B. ET AL.: THE EFFECT OF... awareness of the phenomena could assist in avoiding adverse consequences induced by $\mathrm{CB}$, the determinants of the maladaptive buying behaviour have received increasing attention in scientific literature.

Saraneva and Sääksjärvi (2008) summarised previous research on the determinants of $\mathrm{CB}$ and identified a variety of biological, situational, social and psychological determinants to have significant relationships with CB. In addition, Johnson and Attmann (2009) highlighted two primary factors that influence CB: neuroticism and interest in fashion tendencies.

Phau and Woo (2008) state that money is imprinted into people's minds due to unavoidable interaction, which in turn stipulates emotionally sensitive and comparative behaviour between oneself and others - it acts as an attribute of social power, quality, control, and freedom. According to Baker et al. (2013), materialistic consumers assume that possessions are a prerequisite for life satisfaction and well-being. Possessions and acquisitions are their primary criteria used to judge their success and that of others. Consumers who perceive money as guaranteeing power, prestige, and social hierarchy improvement, who lack self-confidence, are price-insensitive, and have difficulty planning for their financial future, tend to be more engaged in $\mathrm{CB}$. Besides poor self-esteem and propensity to associate social status with consumption, compulsive customers are reported to be highly reliant on materialistic values (Yurchisin \& Johnson, 2004). As CB is aimed at restoring positive mood and developing an identity, materialism has continuously been correlated to CB (Baker et al., 2013; Dittmar, 2005; Mowen \& Spears, 1999; Müller et al., 2014; Roberts et al., 2008). Thus:

$\mathrm{H} 3$ : Materialism is positively related to compulsive buying.

\section{The mediating role of materialism}

A review of literature suggests that material orientation and possessions might function as a coping mechanism for undesirable emotional states (Kasser et al., 2004; Lastovicka \& Sirianni, 2011; Segev et al., 2015). In line with the escape theory, attempts to compensate personal deficiencies (accompanied by negative emotions) may be turned into external forms of self-fulfilment, manifested as materialistic desires (Reeves et al., 2012). Since excessive negative emotions are more prevalent among those scoring low on EI, attachment to possessions as a relief from a painful emotional state is presupposed to be linked with low EI. Emotions and their appraisal inform behavioural responses (Bagozzi et al., 1999). Negative emotional responses to the unpleasant appraisal of life events may provoke, among others, avoidance-based intention response (Bagozzi, 1992). It follows that low EI as poor ability to 
DRUŠ. ISTRAŽ. ZAGREB GOD. 30 (2021), BR. 3, STR. $487-508$

ŠEINAUSKIENĖ, B. ET AL.: THE EFFECT OF... understand and manage personal emotions as well as to cope with negative feelings should lead to the avoidance-based coping style and, therefore, should stimulate the development of materialistic aspirations, which in turn may exhibit a higher tendency towards CB. Thus:

H4a: Materialism mediates the path relationship between understanding one's emotions and compulsive buying.

$\mathrm{H} 4 \mathrm{~b}$ : Materialism mediates the path relationship between managing one's emotions and compulsive buying.

Figure 1 presents the conceptual model.

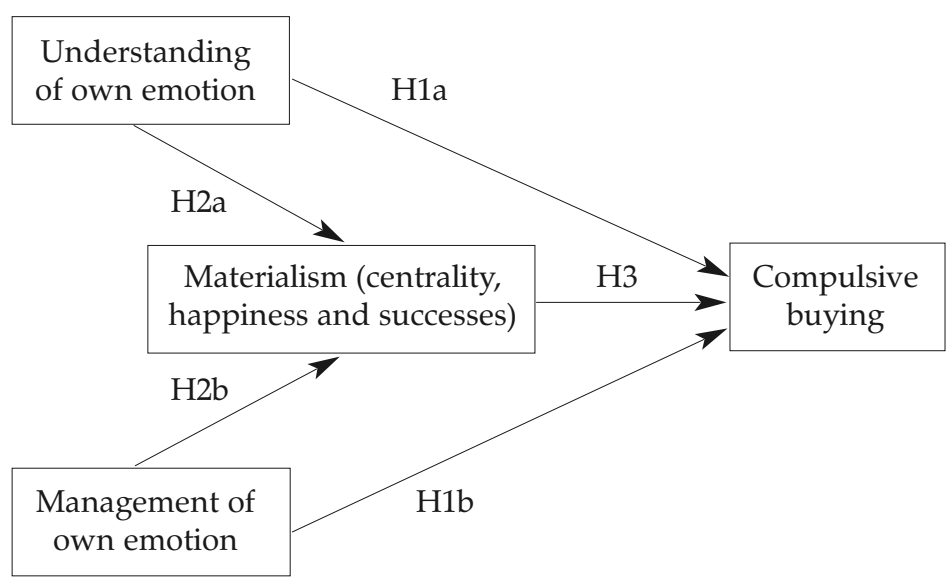

\section{RESEARCH METHODOLOGY}

\section{Data collection}

The survey was conducted from November 2017 to March 2018. Previous research had identified the relation between age and CB behaviour - young people (late teens and young adolescents) present a higher vulnerability to CB (Granero et al., 2016; Villardefrancos \& Otero-López, 2016). Therefore, a questionnaire was distributed to university students, using a convenience sample technique. The data were collected at different universities in Lithuania. 724 responses fully completed and usable for the purposes of the study were utilised for the analysis. We performed two different non-response bias tests. First, the approach recommended by Lau et al. (2010) was used throughout the $t$-test, comparing average scores for the main variables of the first $10 \%$ of the respondents and the last $10 \%$ of the respondents. The results revealed no significant difference between the two compared groups. Moreover, we performed another test with regard to the age and gender of the respondents who responded to our 
DRUŠ. ISTRAŽ. ZAGREB GOD. 30 (2021), BR. 3, STR. 487-508

ŠEINAUSKIENĖ, B. ET AL.: THE EFFECT OF...

\section{Measures}

\section{DATA ANALYSIS AND RESULTS}

In the following sections, we illustrate and discuss the analysis results. We followed the procedures recommended by Anderson and Gerbing (1988) to examine the measurement model and the structural model.

\section{Measurement model}

We used SmartPLS v.3 software to examine the internal consistency and to test the discriminant validity of the measures for all constructs. To examine convergent validity, three criteria were evaluated: all items' factor loadings, Cronbach's alpha, and average variances extracted (AVE). The standardised item loadings for each construct are illustrated in Table 1 
DRUŠ. ISTRAŽ. ZAGREB

GOD. 30 (2021), BR. 3, STR. $487-508$

ŠEINAUSKIENĖ, B. ET AL.: THE EFFECT OF..

(1) TABLE 1

Measurement items and internal validity items from materialism were deleted from the measurement model and further analysis due to low loadings. Cronbach's alpha $(\alpha)$ values were all above the threshold of 0.70 . The AVE values ranged from 0.50 to 0.61 , all complying with the recommended minimum of 0.50 (Bagozzi \& Yi, 1988), and providing strong support for internal consistency. The $\mathrm{CR}$ values ranged from 0.72 to 0.87 , see Table 1 .

\begin{tabular}{l} 
Constructs \\
\hline Understanding one's \\
emotions (Lekavičiene \& \\
Antiniené, 2017) subscale \\
of EI-DARL test (not true \\
of me; strongly disagree \\
(1) to true of me; strongly \\
agree (6))
\end{tabular}

Managing one's emotions (Lekavičienè \& Antinienè, 2017) subscale of EI-DARL test (not true of me; strongly disagree (1) to true of me; strongly agree (6))

Materialism (centrality, happiness and success) (Richins, 2004) (strongly disagree (1) to strongly agree (5))
Compulsive buying

(Edwards, 1993) (strongly disagree (1) to strongly agree (5))

Items

Sometimes I am very sad, and I do not know why.

Sometimes I am angry, and I do not know why.

Sometimes it seems that I am so confused for no reason that I want to cry.

Sometimes I do not understand why I am feeling one way or another.

Sometimes I have feelings that I cannot define. (r)

I find it difficult to understand my feelings.
( $\alpha) \quad 0.86$
CR 0.90
AVE 0.59

I know how to control my feelings in everyday situations.

Sometimes my emotions are so strong that it is difficult

to control them.

I lose self-control easily.

I am able to remain calm when others try to provoke me.

I can control my emotions in critical situations.

I have a hard time dealing with a bad mood.

I manage my moods well, therefore I overcome difficulties in a reasonable manner.

$\begin{array}{ll}(\alpha) & 0.85 \\ \text { CR } & 0.89 \\ \text { AVE } & 0.52\end{array}$

I usually buy only the things I need.

I try to keep my life simple, as far as possessions are concerned.

I enjoy spending money on things that are not that practical.

Buying things gives me a lot of pleasure.

I like a lot of luxury in my life.

It sometimes bothers me quite a bit that I cannot afford to buy all the things I'd like.

I admire people who own expensive homes, cars, and clothes. I like to own things that impress people.

$\begin{array}{ll}(\alpha) & 0.72 \\ \text { CR } & 0.80 \\ \text { AVE } & 0.50\end{array}$

I feel driven to shop and spend, even when I do not have the time or the money.

I go on buying binges.

I buy things even when I do not need anything.

I worry about my spending habits but still go out and shop and spend money.

I buy things even though I cannot afford them.

I buy things I do not need or will not use.

0.71

0.69

0.71

0.69

0.71

0.69

$\begin{array}{lll}0.73 & 2.38 & 1.42\end{array}$

$0.71 \quad 2.51 \quad 1.16$
( $\alpha) \quad 0.87$
CR 0.90
AVE $\quad 0.61$ 
DRUŠ. ISTRAŽ. ZAGREB GOD. 30 (2021), BR. 3, STR. 487-508

ŠEINAUSKIENĖ, B. ET AL.: THE EFFECT OF...

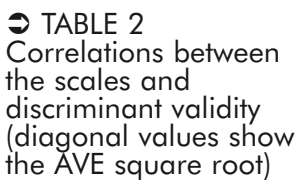

Discriminant validity was assessed to see if each construct's AVE square root was greater than its highest correlation with any other construct in the analysis, and results show no discriminant validity issue, see Table 2 . Discriminant validity assessment guarantees the uniqueness of a measurement construct. It also shows that the phenomenon of interest is not captured in other latent variables within the conceptual model (Hair et al., 2010). It has been argued that the square root of AVE in each latent variable is to be used for examining and establishing discriminant validity (Fornell \& Larcker, 1981). The recommended value for establishing discriminant validity should be larger than other correlation values among the latent variables, see Table 2 .

\begin{tabular}{llrrrr}
\hline & 1 & 2 & 3 & 4 \\
\hline 1 Compulsive buying & 0.780 & & & \\
2 & Managing one's emotions & -0.328 & 0.724 & & \\
3 & Materialism & 0.652 & -0.307 & 0.579 & \\
4 & Understanding one's emotions & -0.266 & 0.587 & -0.226 & 0.767 \\
\hline
\end{tabular}

In order to assess whether multicollinearity was an issue or not, variance inflation factors (VIF) were computed. This test showed that the highest VIF value is 1.86 , well below the threshold of 3.3, therefore, multicollinearity was not an issue (Petter et al., 2007). We performed two different tests to examine common method bias. First, Harman's single-factor test was computed, revealing that the majority of variance could not be attributed to only one factor, and the first factor accounted for $34 \%$ of the variance (Podsakoff et al., 2003). In the second approach, we followed procedures recommended by Malhotra et al. (2006), i.e. a marker-variable technique, and modelled all items as the indicators of a factor; the results showed poor model fit, thus establishing that CMB was not an issue in this study.

\section{Structural model results}

As the measurement model exhibited good measurement properties, in the next step of the analysis we examined the model through Structural Equation Modelling (SEM) using Smart PLS v.3 software. We examined the hypotheses through the assessment of path coefficients. As indicated in Figure 2, compulsive buying (CB) was explained by a variance of $45 \%$, showing that the predictors, materialism and the two dimensions of emotional intelligence (i.e., understanding of one's emotion and management of one's emotion), explained a large amount of variation. The SEM results also showed that materialism was explained by a variance of $11 \%$. In contrast to our 
DRUŠ. ISTRAŽ. ZAGREB GOD. 30 (2021), BR. 3, STR. $487-508$

ŠEINAUSKIENĖ, B. ET AL.: THE EFFECT OF...

\section{○ FIGURE 2 \\ Conceptual model results}

expectations, the SEM results showed that understanding of one's emotions has no direct effect on materialism; therefore, H2a was not supported by the model. The analysis, however, revealed that there is a direct relationship between understanding of one's emotions and CB, thus H1a was supported by the model. It should be noted that the effect was somewhat weak $(\beta=-0.07, p<0.05)$. Furthermore, the results showed that the management of one's emotions has a negative direct effect on materialism, therefore, $\mathrm{H} 2 \mathrm{~b}(\beta=-0.27, p<0.001)$ was supported by the model. Moreover, the analysis revealed that there is a negative direct relationship between the management of one's emotions and CB $(\beta=-0.10, p<0.05)$, thus supporting $\mathrm{H} 1 \mathrm{~b}$. The SEM results showed that there is a significant effect of materialism on $\mathrm{CB}(\beta=0.61, p<0.001)$, thus supporting H3 in our model.

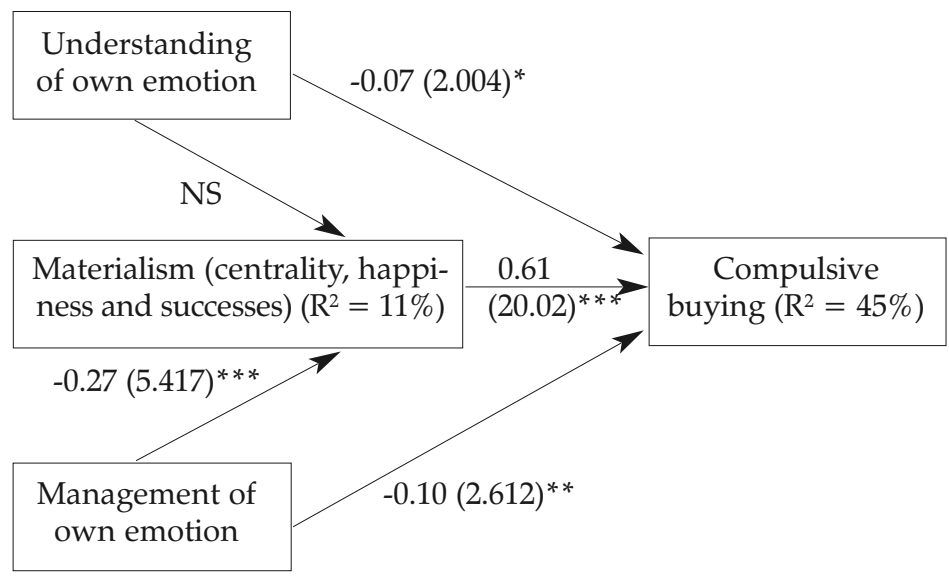

Note: ${ }^{*} p<0.05,{ }^{* *} p<0.01$ and ${ }^{* * *} p<0.001$. The value in the parenthesis represents the $t$-test value

In order to examine whether the relationships between understanding of one's emotions and management of one's emotions to $\mathrm{CB}$ were mediated through materialism, we performed the mediation test. We first accounted for the value of total indirect effects and then examined the direct effects. These two values must be checked for testing the mediation effects when PLS-SEM is used (Hair et al., 2017). We do so to check if the indirect effect is significant or not. If it is not significant, then there is no mediation. If significant, then we check for significance of the direct effects to determine the type of mediation (i.e., full or partial). The total indirect effects for the path between understanding of one's emotions and CB revealed to be not significant, thus materialism does not operate as a mediator in the relationship (Hair et al., 2017; Mat- 
DRUŠ. ISTRAŽ. ZAGREB GOD. 30 (2021), BR. 3, STR. 487-508

ŠEINAUSKIENĖ, B. ET AL.: THE EFFECT OF... thews et al., 2018, p. 3), and H4a was rejected in the model. However, the total indirect effects between management of one's emotions and $\mathrm{CB}$ revealed to be significant $(\beta=-0.16, t=5.195$, $p=0.001)$, establishing the existence of mediation in this path relationship. Therefore, we examined the direct effects $\beta=-0.10$, $t=2.612, p<0.01$ ), and the results showed that materialism partially mediates the path between management of one's emotions and CB, thus, $\mathrm{H} 4 \mathrm{~b}$ was supported.

Taking the results of the SEM analysis and the coefficients of the determinants of $\mathrm{CB}$, materialism emerged as the most powerful predictor relative to other constructs in the model.

\section{DISCUSSION AND CONCLUSIONS}

The assumption that emotional intelligence (understanding one's emotions and managing one's emotions) is negatively associated with the propensity to $\mathrm{CB}$ found empirical support in the present study and is congruent with previous studies (Rose \& Segrist, 2012). The findings of this study revealed that those who score low on EI (concerning the management of one's emotions) exhibit a higher propensity towards CB. Managing one's emotions is related to a higher degree of self-control, while CB, on the contrary, exhibits uncontrollable behaviour and shows weak rational decision-making abilities. Being unable to manage their excessive negative emotions, consumers try to avoid these unpleasant emotional experiences by engaging in CB. Similarly, in line with expectations, the link between EI (with respect to understanding one's emotions) and $\mathrm{CB}$ was confirmed, implying that consumers who face difficulties in identifying and understanding feelings are more likely to engage in CB. Thus, the findings of the present study suggest that understanding and managing one's emotions may act as protecting factors against CB.

Furthermore, as expected, we found management of one's emotions (as a dimension of EI) to be negatively related to materialism. Interestingly, the negative effect of understanding one's emotions (the other dimension of EI) on materialism was found not to be in line with theoretical predictions. Contrary to expectations, the relationship between understanding one's emotions and materialism was insignificant. Such a finding partly echoes those of Ciarrochi et al. (2002), who found that emotionally perceptive people appear to be more strongly affected by stress and show greater rates of depression and hopelessness. One of the possible explanations proposed by the mentioned authors is deliberate insensitivity. Though acknowledging their difficulties, these people tend to repress their negative thoughts or ignore them. Similarly, 
DRUŠ. ISTRAŽ. ZAGREB GOD. 30 (2021), BR. 3, STR. $487-508$

ŠEINAUSKIENĖ, B. ET AL.: THE EFFECT OF... in the study by Aradilla-Herrero et al. (2014), emotional attention, described as a facet of perceived emotional intelligence, has been demonstrated as a predictor of heightened emotional susceptibility and suicidal ideation. The mentioned studies suggest that excessive negative emotions may not be exclusively specific to those who have a lesser understanding of their own emotions. Moreover, the EI construct exhibits conceptual overlap with the concept of psychological mindedness (Taylor et al., 1999). High psychological mindedness produces an increased emotional awareness including the aspects of the self that are intolerable and perceived as insurmountable (Faber \& O'Guinn, 1989). In this sense, a too high degree of psychological mindedness is suggested to be disadvantageous, as it may induce heightened self-criticism and self-discrepancies. Incongruities in the self-concept further motivate consumers to undertake compensatory consumer behaviour, which may take the form of overconsumption, among other things (Mandel et al., 2017). Taken together, the contradicting results of the previous and current study on the effect of understanding one's emotions suggest the existence of boundary conditions or different underlying mechanisms, which could explain the inconsistencies and be the avenues for further research. Future research could account for the effects of specific negative emotions and resulting cognitive coping strategies, since the coping style may depend on the particular emotions elicited by the event (Bagozzi, 1992).

Finally, it was expected and found that materialism mediates the relationship between the management of one's emotions to CB. Presumably, reduced ability to manage personal emotions may reinforce materialistic aspirations, which in turn may develop a higher tendency towards CB. However, our results did not provide support for the assumption that materialism functions as the mediator between understanding one's emotions and CB. Again, the non-significant path of understanding of one's emotions and materialism hints at the possibility of intervening or moderating variables, given that the assumption of both positive (Mikolajczak et al., 2009; Petrides et al., 2007) and adverse (Aradilla-Herrero et al., 2014) effect on adaptive coping can be drawn from the literature.

In line with the theoretical proposition, materialism was positively, statistically related to $\mathrm{CB}$. The prevalence of materialistic values translates into a heightened inclination towards CB. These results are in-line with previous studies (Dittmar, 2005; Harnish \& Bridges, 2015; Islam et al., 2017; Yurchisin \& Johnson, 2004; O'Guinn \& Faber, 1989). The more consumers 
DRUŠ. ISTRAŽ. ZAGREB GOD. 30 (2021), BR. 3, STR. 487-508

ŠEINAUSKIENĖ, B. ET AL.: THE EFFECT OF... adore material rewards as a pivotal goal in their lives, and the more they see material possessions as a critical route towards happiness and success, the more they are preoccupied with materialistic inspirations.

Research findings suggest that the ability to understand and manage one's emotions leads towards individuals' critical reflection on materialistic values. Therefore, encouragement and contribution to the development of emotional intelligence, as well as providing a basis for prevention and consumer education about unrealistic expectations of material goods, are urgent issues in today's societies. Although this study contributes to the literature on antecedents of materialism and $\mathrm{CB}$, it has cross-sectional research design-related limitations, which prevent claims of causation. In addition, the respondents were university students, so the generalisability of research findings to other populations is restricted.

\section{REFERENCES}

Anderson, J. C., \& Gerbing, D. W. (1988). Structural equation modelling in practice: A review and recommended two-step approach. Psychological Bulletin, 103(3), 411-423. https://doi.org/10.1037/0033-2909. 103.3.411

Aradilla-Herrero, A., Tomás-Sábado, J., \& Gómez-Benito, J. (2014). Associations between emotional intelligence, depression and suicide risk in nursing students. Nurse Education Today, 34(4), 520-525. https://doi. org/10.1016/j.nedt.2013.07.001

Bagozzi, R. P. (1992). The self-regulation of attitudes, intentions, and behavior. Social Psychology Quarterly, 55(2), 178-204. https://doi.org/ $10.2307 / 2786945$

Bagozzi, R. P., \& Yi. Y. (1988). On the evaluation of structural equation models. Journal of the Academy of Marketing Science, 16(1), 74-94. https://doi.org/10.1007/BF02723327

Bagozzi, R. P., Gopinath, M., \& Nyer, P. U. (1999). The role of emotions in marketing. Journal of the Academy of Marketing Science, 27(2), 184-206. https://doi.org/10.1177/0092070399272005

Baker, A. M., Moschis, G. P., Benmoyal-Bouzaglo, S., \& Pizzutti dos Santos, C. (2013). How family resources affect materialism and compulsive buying: A cross-country life course perspective. Cross-Cultural Research, 47(4), 335-362. https://doi.org/10.1177/1069397112473074

Bar-On, R. (2006). The Bar-On model of emotional-social intelligence (ESI). Psicothema, 18, 13-25. http://www.psicothema.es/pdf/3271.pdf

Beranuy, M., Oberst, U., Carbonell, X., \& Chamarro, A. (2009). Problematic Internet and mobile phone use and clinical symptoms in college students: The role of emotional intelligence. Computers in $\mathrm{Hu}$ man Behavior, 25(5), 1182-1187. https://doi.org/10.1016/j.chb.2009.03.001

Burroughs, J. E., \& Rindfleisch, A. (2002). Materialism and well-being: A conflicting values perspective. Journal of Consumer Research, 29(3), 348-370. https://doi.org/10.1086/344429 
DRUŠ. ISTRAŽ. ZAGREB GOD. 30 (2021), BR. 3, STR. $487-508$

ŠEINAUSKIENĖ, B. ET AL.: THE EFFECT OF...
Burroughs, J. E., Chaplin, L. N., Pandelaere, M., Norton, M. I., Ordabayeva, N., Gunz, A., \& Dinauer, L. (2013). Using motivation theory to develop a transformative consumer research agenda for reducing materialism in society. Journal of Public Policy \& Marketing, 32(1), 18-31. https://doi.org/10.1509/jppm.10.046

Chang, S. J., Van Witteloostuijn, A., \& Eden, L. (2010). From the editors: Common method variance in international business research. Journal of International Business Studies 41(2), 178-184. https://doi.org/ 10.1057/jibs.2009.88

Chapman, A. L., Gratz, K. L., \& Brown, M. Z. (2006). Solving the puzzle of deliberate self-harm: The experiential avoidance model. Behaviour Research and Therapy, 44(3), 371-394. https://doi.org/10.1016/ j.brat.2005.03.005

Chien-Huang, L., \& Chuang, S. C. (2005). The effect of individual differences on adolescents' impulsive buying behavior. Adolescence, 40(159), 551-558. https://eric.ed.gov/?id=EJ725074

Ciarrochi, J., Deane, F. P., \& Anderson, S. (2002). Emotional intelligence moderates the relationship between stress and mental health. Personality and Individual Differences, 32(2), 197-209. https://doi.org/ 10.1016/S0191-8869(01)00012-5

Dittmar, H. (2004). Understanding and diagnosing compulsive buying. In R. H. Coombs (Ed.), Handbook of addictive disorders: A practical guide to diagnosis and treatment (pp. 411-450). John Wiley \& Sons, Inc.

Dittmar, H. (2005). Compulsive buying - a growing concern? An examination of gender, age, and endorsement of materialistic values as predictors. British Journal of Psychology, 96(4), 467-491. https://doi. org/10.1348/000712605X53533

Dittmar, H., Long, K., \& Bond, R. (2007). When a better self is only a button click away: Associations between materialistic values, emotional and identity-related buying motives, and compulsive buying tendency online. Journal of Social and Clinical Psychology, 26(3), 334361. https://doi.org/10.1521/jscp.2007.26.3.334

Dittmar, H., Bond, R., Hurst, M., \& Kasser, T. (2014). The relationship between materialism and personal well-being: A meta-analysis. Journal of Personality and Social Psychology, 107(5), 879-924. https://doi. org/10.1037/a0037409

Donnelly, G. E., Ksendzova, M., Howell, R. T., Vohs, K. D., \& Baumeister, R. F. (2016). Buying to blunt negative feelings: Materialistic escape from the self. Review of General Psychology, 20(3), 272-316. https://doi.org/10.1037/gpr0000078

Edwards, E. A. (1993). Development of a new scale for measuring compulsive buying behaviour. Financial Counseling and Planning, 4, 67-84. https://doi.org/10.1037/t22901-000

Engelberg, E., \& Sjöberg, L. (2004). Emotional intelligence, affect intensity, and social adjustment. Personality and Individual Differences, 37(3), 533-542. https://doi.org/10.1016/j.paid.2003.09.024

Engelberg, E., \& Sjöberg, L. (2006). Money attitudes and emotional intelligence. Journal of Applied Social Psychology, 36(8), 2027-2047. https://doi. org/10.1111/j.0021-9029.2006.00092.x 
DRUŠ. ISTRAŽ. ZAGREB GOD. 30 (2021), BR. 3, STR. 487-508

ŠEINAUSKIENĖ, B. ET AL.: THE EFFECT OF...
Faber, R. J., \& O'Guinn, T. C. (1989). Classifying compulsive consumers: Advances in the development of a diagnostic tool. Advances in Consumer Research, 16, 738-744. http://www.acrwebsite.org/volumes/ 5965/volumes/v16/NA-16

Fornell, C., \& Larcker, D. F. (1981). Evaluating structural equation models with unobservable variables and measurement error. Journal of Marketing Research, 18 (1), 39-50. https://doi.org/10.1177/002224378 101800104

Granero, R., Fernández-Aranda, F., Steward, T., Mestre-Bach, G., Baño, M., del Pino-Gutiérrez, A., Moragas, L., Aymamí, N., Gómez-Peña, M., Mallorquí-Bagué, N., Tárrega, S., Menchón, J. M., \& Jiménez-Murcia, S. (2016). Compulsive buying behavior: Characteristics of comorbidity with gambling disorder. Frontiers in Psychology, 7, 625. https://doi.org/10.3389/fpsyg.2016.00625

Hair, J. F., Black, W. C., Babin, B. J., \& Anderson, R. E. (2010). Multivariate data analysis (7th ed.). Prentice Hall.

Hair, J. F., Hult, G. T. M., Ringle, C. M., \& Sarstedt, M. (2017). A Primer on Partial Least Squares Structural Equation Modeling (PLS-SEM), 2nd Ed. SAGE Publications, Inc. https://doi.org/10.15358/9783800653614

Harnish, R. J., \& Bridges, K. R. (2015). Compulsive buying: The role of irrational beliefs, materialism, and narcissism. Journal of Rational-Emotive \& Cognitive-Behavior Therapy, 33(1), 1-16. https://doi.org/10. 1007/s10942-014-0197-0

Hayes, S. C., Wilson, K. G., Gifford, E. V., Follette, V. M., \& Strosahl, K. (1996). Experiential avoidance and behavioral disorders: A functional dimensional approach to diagnosis and treatment. Journal of Consulting and Clinical Psychology, 64(6), 1152-1168. https://doi.org/10.1037/ 0022-006X.64.6.1152

Heatherton, T. F., \& Baumeister, R. F. (1991). Binge eating as escape from self-awareness. Psychological Bulletin, 110(1), 86-108. https://doi. org/10.1037/0033-2909.110.1.86

Islam, T., Wei, J., Sheikh, Z., Hameed, Z., \& Azam, R. I. (2017). Determinants of compulsive buying behavior among young adults: The mediating role of materialism. Journal of Adolescence, 61, 117-130. https://doi.org/10.1016/j.adolescence.2017.10.004

Johnson, T., \& Attmann, J. (2009). Compulsive buying in a product specific context: Clothing. Journal of Fashion Marketing and Management, 13(3), 394-405. https://doi.org/10.1108/13612020910974519

Kashdan, T. B., \& Breen, W. E. (2007). Materialism and diminished well-being: Experiential avoidance as a mediating mechanism. Journal of Social and Clinical Psychology, 26(5), 521-539. https://doi.org/10. 1521/jscp.2007.26.5.521.

Kasser, T., \& Ahuvia, A. (2002). Materialistic values and well-being in business students. European Journal of Social Psychology, 32(1), 137-146. https://doi.org/10.1002/ejsp.85

Kasser, T., Ryan, R. M., Couchman, C. E., \& Sheldon, K. M. (2004). Materialistic values: Their causes and consequences. In T. Kasser \& 
DRUŠ. ISTRAŽ. ZAGREB GOD. 30 (2021), BR. 3, STR. $487-508$

ŠEINAUSKIENĖ, B. ET AL.: THE EFFECT OF...
A. D. Kanner (Eds.), Psychology and consumer culture: The struggle for a good life in a materialistic world (pp. 11-28). American Psychological Association. https://doi.org/10.1037/10658-002

Kellett, S., \& Bolton, J. V. (2009). Compulsive buying: A cognitivebehavioural model. Clinical Psychology E Psychotherapy: An International Journal of Theory \& Practice, 16(2), 83-99. https://doi.org/10.1002/cpp.585

Kidwell, B., Hardesty, D. M., \& Childers, T. L. (2008). Consumer emotional intelligence: Conceptualization, measurement, and the prediction of consumer decision making. Journal of Consumer Research, 35(1), 154-166. https://doi.org/10.1037/10658-002

Kun, B., \& Demetrovics, Z. (2010). Emotional intelligence and addictions: A systematic review. Substance Use \& Misuse, 45(7-8), 11311160. https://doi.org/10.1002/cpp.585

Lastovicka, J. L., \& Sirianni, N. J. (2011). Truly, madly, deeply: Consumers in the throes of material possession love. Journal of Consumer Research, 38(2), 323-342. https://doi.org/10.1086/658338

Lau, A. K. W., Tang, E., \& Yam, R. C. M. (2010). Effects of suppliers and customer integration on product innovation and performance: Empirical evidence in Hong Kong manufacturers. Journal of Product Innovation Management, 27(5), 761-777. https://doi.org/10.1111/j.15405885.2010.00749.x

Lekavičienė, R., \& Antinienė, D. (2017). Important factors for successful solution of emotional situations: Empirical study on young people. World Academy of Science, Engineering and Technology: International Journal of Economic and Management Engineering, 11(6), 1418-1422. http://waset.org/publications/10007269

Malhotra, N. K., Kim, S. S., \& Patil, A. (2006). Common method variance in IS research: A comparison of alternative approaches and a reanalysis of past research. Management Science, 52(12), 1865-1883. https://doi.org/10.1287/mnsc.1060.0597

Mandel, N., Rucker, D. D., Levav, J., \& Galinsky, A. D. (2017). The compensatory consumer behavior model: How self-discrepancies drive consumer behavior. Journal of Consumer Psychology, 27(1), 133-146. https://doi.org/10.1016/j.jcps.2016.05.003

Maraz, A., Griffiths, M. D., \& Demetrovics, Z. (2016). The prevalence of compulsive buying: A meta-analysis. Addiction, 111(3), 408-419. https://doi.org/10.1111/add.13223

Maraz, A., Eisinger, A., Hende, B., Urbán, R., Paksi, B., Kun, B., Kökönyei, G., Griffiths, M. D., \& Demetrovics, Z. (2015). Measuring compulsive buying behaviour: Psychometric validity of three different scales and prevalence in the general population and in shopping centres. Psychiatry Research, 225(3), 326-334. https://doi.org/10.1016/j. psychres.2014.11.080

Matthews, G., Emo, A. K., Funke, G., Zeidner, M., Roberts, R. D., Costa Jr, P. T., \& Schulze, R. (2006). Emotional intelligence, personality, and task-induced stress. Journal of Experimental Psychology: Applied, 12(2), 96-107. https://doi.org/10.1037/1076-898X.12.2.96 
DRUŠ. ISTRAŽ. ZAGREB GOD. 30 (2021), BR. 3, STR. $487-508$

ŠEINAUSKIENĖ, B. ET AL. THE EFFECT OF...
Matthews, L., Hair, J. O. E., \& Matthews, R. (2018). PLS-SEM: The Holy grail for advanced analysis. Marketing Management Journal, 28(1), 1-13.

Mayer, J. D., \& Salovey, P. (1997). What is emotional intelligence? In P. Salovey \& D. J. Sluyter (Eds.), Emotional development and emotional intelligence: Educational implications (pp. 3-34). Basic Books.

Mayer, J. D., Salovey, P., \& Caruso, D. R. (2004). Emotional intelligence: Theory, findings, and implications. Psychological Inquiry, 15(3), 197-215. https://doi.org/10.1207/s15327965pli1503_02

Mikolajczak, M., Petrides, K. V., \& Hurry, J. (2009). Adolescents choosing self-harm as an emotion regulation strategy: The protective role of trait emotional intelligence. British Journal of Clinical Psychology, 48(2), 181-193. https://doi.org/10.1348/014466508X386027

Mikolajczak, M., Nelis, D., Hansenne, M., \& Quoidbach, J. (2008). If you can regulate sadness, you can probably regulate shame: Associations between trait emotional intelligence, emotion regulation and coping efficiency across discrete emotions. Personality and Individual Differences, 44(6), 1356-1368. https://doi.org/10.1016/j.paid.2007.12.004

Moschis, G. P. (2017). Research frontiers on the dark side of consumer behaviour: The case of materialism and compulsive buying. Journal of Marketing Management, 33(15-16), 1384-1401. https://doi. org/10.1080/0267257X.2017.1347341

Mowen, J. C., \& Spears, N. (1999). Understanding compulsive buying among college students: A hierarchical approach. Journal of Consumer Psychology, 8(4), 407-430. https://doi.org/10.1207/s15327663jcp0804_03 Müller, A., Mitchell, J. E., Crosby, R. D., Cao, L., Johnson, J., Claes, L., \& de Zwaan, M. (2012). Mood states preceding and following compulsive buying episodes: An ecological momentary assessment study. Psychiatry Research, 200(2), 575-580. https://doi.org/10.1016/j. psychres.2012.04.015

Müller, A., Claes, L., Georgiadou, E., Möllenkamp, M., Voth, E. M., Faber, R. J., Mitchell, J. E., \& de Zwaan, M. (2014). Is compulsive buying related to materialism, depression or temperament? Findings from a sample of treatment-seeking patients with compulsive buying. Psychiatry Research, 216(1), 103-107. https://doi.org/10.1016/j.psychres.2014.01.012

Müller, J., \& Roberts, J. E. (2005). Memory and attention in obsessivecompulsive disorder: A review. Journal of Anxiety Disorders, 19(1), 1-28. https://doi.org/10.1016/j.janxdis.2003.12.001

O'Guinn, T. C., \& Faber, R. J. (1989). Compulsive buying: A phenomenological exploration. Journal of Consumer Research, 16(2), 147-157. https://doi.org/10.1086/209204

Otero-López, J. M., \& Pol, E. V. (2013). Compulsive buying and the Five Factor Model of personality: A facet analysis. Personality and Individual Differences, 55(5), 585-590. https://doi.org/10.1016/j.paid. 2013.05.005

Otero-López, J. M., Pol, E. V., Bolaño, C. C., \& Mariño, M. J. S. (2011). 
DRUŠ. ISTRAŽ. ZAGREB GOD. 30 (2021), BR. 3, STR. $487-508$

ŠEINAUSKIENĖ, B. ET AL.: THE EFFECT OF... causal relationships. Personality and Individual Differences, 50(6), 772-776. https://doi.org/10.1016/j.paid.2010.12.027

Parker, J. D., Taylor, R. N., Eastabrook, J. M., Schell, S. L., \& Wood, L. M. (2008). Problem gambling in adolescence: Relationships with internet misuse, gaming abuse and emotional intelligence. Personality and Individual Differences, 45(2), 174-180. https://doi.org/10.1016/j. paid.2008.03.018

Petrides, K. V., \& Furnham, A. (2001). Trait emotional intelligence: Psychometric investigation with reference to established trait taxonomies. European Journal of Personality, 15(6), 425-448. https://doi.org/ 10.1002/per.416

Petrides, K. V., Pita, R., \& Kokkinaki, F. (2007). The location of trait emotional intelligence in personality factor space. British Journal of Psychology, 98(2), 273-289. https://doi.org/10.1348/000712606X120618

Petter, S., Straub, D., \& Rai, A. (2007). Specifying formative constructs in information systems research. MIS Quarterly, 31(4), 623-656, https://doi. org/10.2307/25148814

Phau, I., \& Woo, C. (2008). Understanding compulsive buying tendencies among young Australians: The roles of money attitude and credit card usage. Marketing Intelligence \& Planning, 26(5), 441-458. https://doi.org/10.1108/02634500810894307

Podsakoff, P. M., MacKenzie, S. B., Lee, J. Y., \& Podsakoff, N. P. (2003). Common method biases in behavioural research: A critical review of the literature and recommended remedies. Journal of Applied Psychology, 88(5), 879-903. https://doi.org/10.1037/0021-9010.88.5.879

Reeves, R. A., Baker, G. A., \& Truluck, C. S. (2012). Celebrity worship, materialism, compulsive buying, and the empty self. Psychology $\mathcal{E}$ Marketing, 29(9), 674-679. https://doi.org/10.1002/mar.20553

Richins, M. L. (2004). The material values scale: Measurement properties and development of a short form. Journal of Consumer Research, 31(1), 209-219. https://doi.org/10.1086/383436

Richins, M. L., \& Dawson, S. (1992). A consumer values orientation for materialism and its measurement: Scale development and validation. Journal of Consumer Research, 19(3), 303-316. https://doi.org/ $10.1086 / 209304$

Ridgway, N. M., Kukar-Kinney, M., \& Monroe, K. B. (2008). An expanded conceptualization and a new measure of compulsive buying. Journal of Consumer Research, 35(4), 622-639. https://doi.org/10. $1086 / 591108$

Roberts, J. A., Manolis, C., \& Tanner Jr, J. F. (2008). Interpersonal influence and adolescent materialism and compulsive buying. Social Influence, 3(2), 114-131. https://doi.org/10.1080/15534510802185687

Rose, P., \& Segrist, D. J. (2012). Difficulty identifying feelings, distress tolerance and compulsive buying: Analyzing the associations to inform therapeutic strategies. International Journal of Mental Health and Addiction, 10(6), 927-935. https://doi.org/10.1007/s11469-012-9389-y

Sánchez-Álvarez, N., Extremera, N., \& Fernández-Berrocal, P. (2016). The relation between emotional intelligence and subjective well-be- 
DRUŠ. ISTRAŽ. ZAGREB GOD. 30 (2021), BR. 3, STR. 487-508

ŠEINAUSKIENĖ, B. ET AL.: THE EFFECT OF... ing: A meta-analytic investigation. The Journal of Positive Psychology, 11(3), 276-285. https://doi.org/10.1080/17439760.2015.1058968

Saraneva, A. \& Sääksjärvi, M. (2008). Young compulsive buyers and the emotional roller-coaster in shopping. Young Consumers, 9(2), 75-89. https://doi.org/10.1108/17473610810879657

Schneider, T. R., Lyons, J. B., \& Khazon, S. (2013). Emotional intelligence and resilience. Personality and Individual Differences, 55(8), 909-914. https://doi.org/10.1016/j.paid.2013.07.460

Segev, S., Shoham, A., \& Gavish, Y. (2015). A closer look into the materialism construct: The antecedents and consequences of materialism and its three facets. Journal of Consumer Marketing, 32(2), 85-98. https://doi.org/10.1108/JCM-07-2014-1082

Shrum, L. J., Lowrey, T. M., Pandelaere, M., Ruvio, A. A., Gentina, E., Furchheim, P., Herbert, M., Hudders, L., Lens, I., Mandel, N., Nairn, A., Samper, A., Soscia, I., \& Steinfield, L. (2014). Materialism: The good, the bad, and the ugly. Journal of Marketing Management, 30(17-18), 1858-1881. https://doi.org/10.1080/0267257X.2014.959985

Taylor, G. J., Parker, J. D., \& Bagby, R. M. (1999). Emotional intelligence and the emotional brain: Points of convergence and implications for psychoanalysis. Journal of the American Academy of Psychoanalysis, 27(3), 339-354. https://doi.org/10.1521/jaap.1.1999.27.3.339

Villardefrancos, E., \& Otero-López, J. M. (2016). Compulsive buying in university students: Its prevalence and relationships with materialism, psychological distress symptoms, and subjective well-being. Comprehensive Psychiatry, 65, 128-135. https://doi.org/10.1016/j.comppsych. 2015.11.007

Yurchisin, J., \& Johnson, K. K. (2004). Compulsive buying behavior and its relationship to perceived social status associated with buying, materialism, self-esteem, and apparel-product involvement. Family and Consumer Sciences Research Journal, 32(3), 291-314. https://doi.org/ 10.1177/1077727X03261178

Zeidner, M., Matthews, G., \& Roberts, R. D. (2012). The emotional intelligence, health, and well-being nexus: What have we learned and what have we missed? Applied Psychology: Health and Well-Being, 4(1), 1-30. https://doi.org/10.1111/j.1758-0854.2011.01062.x

Zhang, C., Brook, J. S., Leukefeld, C. G., \& Brook, D. W. (2016). Associations between compulsive buying and substance dependence/ abuse, major depressive episodes, and generalized anxiety disorder among men and women. Journal of Addictive Diseases, 35(4), 298-304. https://doi.org/10.1080/10550887.2016.1177809

Zhang, C., Brook, J. S., Leukefeld, C. G., De La Rosa, M., \& Brook, D. W. (2017). Compulsive buying and quality of life: An estimate of the monetary cost of compulsive buying among adults in early midlife. Psychiatry Research, 252, 208-214. https://doi.org/10.1016/j.psychres. 2017.03.007 
DRUŠ. ISTRAŽ. ZAGREB

GOD. 30 (2021), BR. 3, STR. $487-508$

ŠEINAUSKIENĖ, B. ET AL.: THE EFFECT OF...

\section{Učinak emocionalne inteligencije na materijalizam i kompulzivnu kupnju}

Beata ŠEINAUSKIENĖ, Aušra RŪTELIONĖ, Asta TARUTĖ

Škola ekonomije i biznisa,

Tehnološko sveučilište Kaunas, Litva

Shahrokh NIKOU

Fakultet društvenih znanosti, biznisa i ekonomije,

Sveučilište Åbo Akademi, Finska

Rosita LEKAVIČIENÉ

Fakultet društvenih i humanističkih znanosti i umjetnosti,

Tehnološko sveučilište Kaunas, Litva

Oslanjajući se na teoriju bijega, iznosimo tezu da je emocionalna inteligencija negativno povezana $s$

materijalizmom i kompulzivnom kupnjom. Naše istraživanje pokazuje da je sposobnost upravljanja vlastitim emocijama povezana s nižim razinama materijalizma i kompulzivne kupnje. Također upozoravamo na to da materijalizam funkcionira kao mehanizam koji utječe na odnos emocionalne inteligencije i kompulzivne kupnje. Nadalje, utvrđeno je da je sposobnost razumijevanja vlastitih emocija negativno povezana s kompulzivnom kupnjom. Suprotno očekivanjima, analizom putanje vočeno je da je odnos između razumijevanja vlastitih emocija i materijalizma beznačajan, što upućuje na to da veza između emocionalne inteligencije i materijalizma možda nije uvijek izravna.

Očekivano, materijalizam je bio pozitivno povezan s kompulzivnom kupnjom. Naše istraživanje pridonosi relevantnoj literaturi, otkrivajući da emocionalna inteligencija prethodi materijalizmu.

Ključne riječi: emocionalna inteligencija, kompulzivna kupnja, materijalizam, teorija bijega

\section{(c) (i) (5)}

Međunarodna licenca / International License:

Imenovanje-Nekomercijalno / Attribution-NonCommercial 